\title{
PENGARUH KEPUTUSAN INVESTASI DAN KEPUTUSAN PENDANAAN TERHADAP PROFITABILITAS DAN NILAI PERUSAHAAN PADA LQ-45
}

\author{
Nika Ardila', Nur Aida Arifah Tara ${ }^{2}$, Burhanudin ${ }^{3}$ \\ ${ }^{123}$ Faculty of Economics and Business, University of Mataram, Indonesia.
} Email:nardila1611@gmail.com

nuraida.tara@unram.ac.id

\begin{tabular}{|c|c|}
\hline ARTICLE INFO & ABSTRACT \\
\hline $\begin{array}{l}\text { Keywords: } \\
\text { Investment Decision, Funding Decision, } \\
\text { Profitability, Firm Value } \\
\text { Kata kunci: } \\
\text { Keputusan Investasi, Keputusan } \\
\text { Pendanaan, Profitabilitas, Nilai } \\
\text { Perusahaan } \\
\text { How to cite: } \\
\text { Ardila, N., Tara, N. A. A., Burhanudin, } \\
\text { B., (2021). Pengaruh Keputusan Investasi } \\
\text { Dan Keputusan Pendanaan Terhadap } \\
\text { Profitabilitas Dan Nilai Perusahaan Pada } \\
\text { LQ-45. } \\
\text { JMM UNRAM, 10(4), 247-258 } \\
\text { DOI: } \\
\text { https://doi.org/10.29303/jmm.v10i4.673 }\end{array}$ & $\begin{array}{l}\text { This study aims to examine the effect of investment and } \\
\text { funding decisions on firm value with profitability as a } \\
\text { mediating variable in companies included in the LQ45 index } \\
\text { for the } 2015-2019 \text { period. The results on the } t \text { test show that } \\
\text { the positive investment decision is not significant to } \\
\text { profitability. The funding decision is negative and not } \\
\text { significant to profitability. Investment decisions are positive } \\
\text { and significant to firm value while negative funding decisions } \\
\text { are not significant to firm value. Profitability is positive and } \\
\text { significant to firm value. The results of the mediation test show } \\
\text { that profitability is not able to mediate the effect of investment } \\
\text { decisions and funding decisions on firm value. } \\
\text { Penelitian ini bertujuan untuk menguji pengaruh } \\
\text { keputusan investasi dan keputusan pendanaan } \\
\text { terhadap nilai perusahaan dengan profitabilitas sebagai } \\
\text { variabel mediasi pada perusahaan yang termasuk ke } \\
\text { dalam indeks LQ45 periode 2015-2019. Hasil pengujian } \\
t \text { menunjukkan keputusan investasi positif tidak } \\
\text { signifikan terhadap profitabilitas. Keputusan } \\
\text { pendanaan negatif dan tidak signifikan terhadap } \\
\text { profitabilitas. Keputusan investasi positif dan signifikan } \\
\text { terhadap nilai perusahaan sedangkan keputusan } \\
\text { pendanaan negatif tidak signifikan terhadap nilai } \\
\text { perusahaan. Profitabilitas positif dan signifikan } \\
\text { terhadap nilai perusahaan. Hasil pengujian mediasi } \\
\text { menunjukkan bahwa profitabilitas tidak mampu } \\
\text { memediasi pengaruh keputusan investasi dan } \\
\text { keputusan pendanaan terhadap nilai perusahaan. }\end{array}$ \\
\hline & $\begin{array}{l}\text { Copyright @ } 2021 \text { Nike Ardila, Nur Aida Arifah Tara, } \\
\text { Burhanudin. All rights reserved. }\end{array}$ \\
\hline
\end{tabular}




\section{PENDAHULUAN}

Tujuan normatif keputusan keuangan adalah memaksimumkan kemakmuran pemegang saham melalui maksimisasi nilai perusahaan (Sartono, 2001:8). Nilai perusahaan merupakan suatu performa manajemen dalam mengelola aktiva perusahaan (Lindenberg \& Ross, 1981; Suroto, 2015). Setiap pemilik perusahaan berusaha memberikan sinyal yang baik kepada publik tentang nilai perusahaan untuk mendapatkan modal dari eksternal untuk meningkatkan kegiatan produksi (Mardiyati et. al., 2015). Semakin tinggi nilai perusahaan menggambarkan semakin sejahtera pula pemiliknya, dan nilai perusahaan akan tercermin dari harga pasar sahamnya (Achmad \& Amanah, 2014). Untuk mencapai memaksimisasi nilai perusahaan, ada beberapa pengambilan keputusan yang dilakukan oleh perusahaan diantaranya ada keputusan investasi, keputusan pendanaan dan kebijakan deviden (Pamungkas \& Puspaningsih, 2013). Namun pada penelitian kali ini hanya akan membahas keputusan investasi dan keputusan pendanaan.

Keputusan investasi merupakan tindakan untuk menanamkan dana yang dimiliki ke dalam aktiva lancar maupun aktiva tetap dengan harapan untuk memperoleh keuntungan dimasa yang akan datang (Salim \& Moeljadi, 2001:110; Suroto, 2015). Keputusan investasi sangat penting dalam keuangan perusahaan karena semakin tinggi keputusan investasi maka semakin tinggi kesempatan perusahaan dalam memperoleh return atau tingkat pengembalian yang besar. Perusahaan akan mendapat laba yang besar dengan resiko yang dapat dikelola dengan harapan dapat mengoptimalkan nilai perusahaan. Keputusan investasi dalam penelitian terdahulu diukur dengan proksi Price Earning Ratio (PER) yang merupakan indikasi penilaian pasar modal terhadap kemampuan perusahaan dalam menghasilkan laba/keuntungan potensial perusahaan dimasa yang akan datang yang menunjukkan seberapa banyak investor bersedia membayar untuk setiap laba yang dilaporkan (Brigham \& Houston, 2011).

Faktor kedua yang mempengaruhi nilai perusahaan adalah keputusan pendanaan. Keputusan pendanaan merupakan keputusan yang dilakukan oleh perusahaan berkaitan dengan peningkatan hutang. Berdasarkan trade off theory, kenaikan hutang akan bermanfaat jika dapat meningkatkan nilai perusahaan, artinya bahwa penambahan hutang belum mencapai titik optimal dimana suatu batas optimal dari jumlah hutang yang dapat menyebabkan nilai perusahaan tersebut maksimal (Mardiyati et. al., 2015). Salah satu rasio yang digunakan untuk mengukur tingkat penggunaan utang di perusahaan adalah Debt to Equity Ratio (DER), yang dapat menunjukkan kemampuan modal sendiri dalam membiayai utang yang dimiliki perusahaan (Sari \& Budiasih, 2014).

Secara umum keputusan investasi dan keputusan pendanaan memiliki pengaruh positif terhadap nilai perusahaan. Tetapi, penelitian terdahulu juga menunjukkan hasil yang berbeda dan tidak konsisten, termasuk hasil penelitian Suroto (2015), Sartini dan Purbawangsa (2014), Gustian (2017), Muvidha dan Suryono (2017), Alipudin dan Hidayat (2014) serta Mardiyati et. al. (2015). Oleh karena perbedaan hasil penelitian terdahulu (research gap), maka akan dilakukan pengujian kembali dengan pengembangan tahun penelitian kedua variabel yaitu keputusan investasi dan keputusan pendanaan serta pengaruhnya terhadap nilai perusahaan LQ45 di Bursa Efek Indonesia (BEI) pada periode 2015-2019 dengan penambahan variabel mediasi, yaitu profitabilitas. Perusahaan yang memiliki profitabilitas yang tinggi dapat menarik minat para investor dalam membeli saham perusahaan karena investor menilai manajemen perusahaan yang telah berhasil mengelola aset dan modal yang dimiliki sampai memperoleh keuntungan yang maksimal. Sehingga dengan demikian besar kecilnya profitabilitas dapat mempengaruhi nilai perusahaan (Septiani, 2019). 
Dalam hal ini investor tentunya akan memilih perusahaan yang memiliki track record yang baik di pasar modal, termasuk saham-saham dalam indeks LQ45 yang terdiri dari 45 saham saham yang memiliki kapitalisasi pasar yang besar dan likuiditas yang tinggi (Rini \& Winarmo, 2016). Berikut disajikan tabel rata-rata pertahun nilai perusahaan LQ45 yang dijadikan sampel dalam penelitian ini adalah sebagai berikut :

Tabel 1. Rata-rata Nilai Perusahaan LQ45 yang Terdaftar di BEI Periode 2015-2019

\begin{tabular}{|c|c|c|}
\hline Tahun & Tobin's Q (x) & Perubahan Tobin's Q (x) \\
\hline 2014 & 2,56 & -22 \\
\hline 2015 & 2,09 & 1 \\
\hline 2016 & 2,11 & 108 \\
\hline 2017 & 4,38 & -159 \\
\hline 2018 & 1,69 & -4 \\
\hline 2019 & 1,62 & \\
\hline
\end{tabular}

Sumber : Data sekunder yang diolah

Dari tabel 1 di atas, dapat diketahui bahwa rata-rata nilai perusahaan mengalami penurunan sebesar -22x dari tahun 2015 (2,09x) ke 2016 (2,11x). Pada tahun 2016 naik menjadi 2,11x dengan perubahan sebesar 1x, dan tahun 2017 mengalami kenaikan yang pesat menjadi 4,38x dengan nilai perubahan sebesar 108x. Selanjutnya pada tahun 2018 nilai perusahaan kembali menurun menjadi 1,69x dengan nilai perubahannyasebesar $-159 x$ dan tahun 2019 turun lagi menjadi 1,62x dengan nilai perubahan sebesar -4x.

Dari penelitian-penelitian sebelumnya masih terdapat perbedaan antara hasil peneliti satu dengan yang lainnya mengenai kemampuan profitabilitas dalam memediasi pengaruh keputusan investasi dan keputusan pendanaan terhadap nilai perusahaan. Penelitian yang dilakukan oleh Kurniawan (2015) menyatakan bahwa keputusan investasi berpengaruh terhadap nilai perusahaan dengan profitabilitas sebagai variabel mediasi. Selanjutnya penelitian oleh Anisa (2019), Hamidy et. al. (2015) dan Makkulau et. al. (2018) mengatakan bahwa profitabilitas dapat memediasi antara struktur modal terhadap nilai perusahaan. Berdasarkan latar belakang yang telah diuraikan diatas, maka dilakukan pengujian kembali terhadap faktor yang mempengaruhi nilai perusahaan.

\section{KAJIAN PUSTAKA}

\subsection{Nilai Perusahaan}

Nilai perusahaan merupakan hasil penjumlahan antara hutang jangkapanjang (loans dan bonds) dengan modal sendiri (equity) (Bararuallo, 2011) dan merupakan persepsi para investor terhadap tingkat keberhasilan perusahaan yang sering dikaitkan dengan harga saham (Hardiyanti, 2012). Nilai perusahaan yang tinggi akan meningkatkan kepercayaan pasar terhadap kinerja dan prospek perusahaan dimasa mendatang. Upaya memaksimalkan nilai perusahaan penting bagi perusahaan karena dengan memaksimalkan nilai perusahaan berarti nilai kemakmuran para pemegang saham juga semakin maksimal sesuai dengan tujuan perusahaan. Jika harga pasar dari suatu saham semakin tinggi, maka kemungkinan pasar mendapatkan capital gain (actual return) juga akan makin tinggi.

\subsection{Keputusan Investasi}

Secara umum investasi diartikan sebagai penanaman modal, baik itu modal tetap atau modal tidak tetap yang digunakan memperoleh keuntungan suatu perusahaan. Investasi juga dapat diartikan sebagai penanaman sumber daya untuk mendapatkan hasil dimasa yang akan datang (Husnan, 2000). Investasi ke dalam aktiva yang produktif akan meningkatkan utilitas. Tujuan dilakukannya keputusan investasi adalah untuk mendapat 
laba yang besar dengan risiko yang dapat dikelola dengan harapan dapat mengoptimalkan nilai perusahaan. Keputusan investasi yang tepat akan berpengaruh positif terhadap profitabilitas (Ginting, 2019; Purnama, 2018; Setiawan \& Sudiro, 2019) dan nilai perusahaan (Rini \& Winarmo, 2016; Sartini \& Purbawangsa, 2014; Suroto, 2015; Maimunah \& Hilal, 2014).

\subsection{Keputusan Pendanaan}

Keputusan pendanaan perusahaan menyangkut keputusan tentang bentuk dan komposisi pendanaan yang akan dipergunakan oleh perusahaan. Secara umum, dana dapat diperoleh dari luar perusahaan (external financing) maupun dari dalam perusahaan (internal financing). Keputusan tentang external financing sering disebut sebagai keputusan pendanaan, sedangkan internal financing menyangkut kebijakan dividen (Husnan, 1996). Keputusan pendanaan merupakan bagian dari struktur modal perusahaan, dan keduanya saling berkaitan dan tidak bisa dipisahkan. Perusahaan lebih menyukai mendapatkan modal dari hutang, namun manajemen harus bijak dalam melakukan modal tersebut. Penggunaan hutang akan meningkatkan nilai perusahaan namun pada sampai waktu dan titik tertentu. Setelah titik tersebut terlewati, penggunaan hutang justru akan menurunkan nilai perusahaan (Muvidha \& Suryono, 2017).

\subsection{Profitabilitas}

Profitabilitas adalah kemampuan perusahaan memperoleh laba terkait dengan penjualan total aktiva maupun modal sendiri atau hasil akhir dari sejumlah kebijakan dan keputusan manajemen perusahaan (Brigham \& Houston, 2009; Sartono, 2001). Dengan demikian dapat dikatakan profitabilitas perusahaan merupakan kemampuan perusahaan dalam menghasilkan laba bersih dari aktivitas yang dilakukan pada periode akuntansi yang menentukan prospek perusahaan di masa yang akan datang (Anisa, 2019; Munawir, 2014:33; Kelana \& Amanah, 2020).

\subsection{Kerangka Konseptual dan Hipotesis}

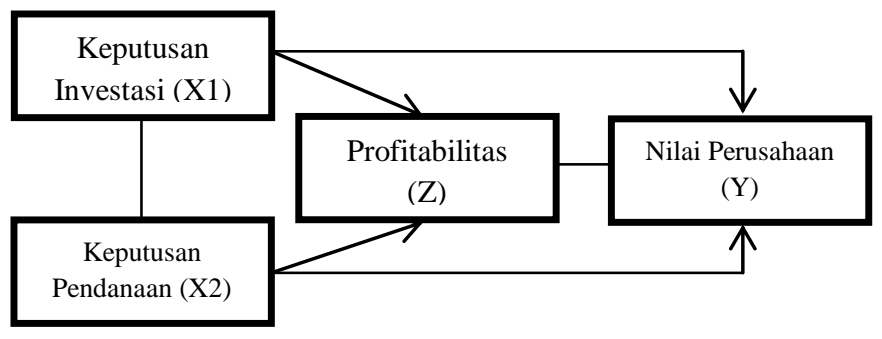

Gb 1. Rerangka Konseptual

$\mathrm{H} 1$ :Keputusan Investasi berpengaruh positif terhadap Profitabilitas

$\mathrm{H} 2$ :Keputusan Pendanaan berpengaruh negatif terhadap Profitabilitas

H3 :Keputusan Investasi berpengaruh positif terhadap Nilai Perusahaan

H4 :Keputusan Pendanaan berpengaruh negatif terhadap Nilai Perusahaan

H5 :Profitabilitas berpengaruh positif terhadap Nilai Perusahaan

H6:Profitabilitas mampu memediasi pengaruh Keputusan Investasi terhadap Nilai Perusahaan

H7 :Profitabilitas mampu memediasi pengaruh Keputusan Pendanaan terhadap Nilai Perusahaan 


\section{METODE PENELITIAN}

Jenis penelitian ini adalah penelitian asosiatif. Penelitian ini bertujuan untuk mengetahui pengaruh antara variabel bebas keputusan investasi dan keputusan pendanaan dengan variabel terikat nilai perusahaan dengan profitabilitas sebagai variabel mediasi pada perusahaan yang termasuk dalam indek LQ45 periode 2015-2019. Sampel penelitian sebanyak 21 perusahaan, dan jenis data dalam penelitian ini adalah data sekunder yang berupa laporan keuangan dan tahunan serta harga saham akhir tahun peusahaan yang termasuk ke dalam indeks LQ45 periode 2015-2019 yang didapat langsung dari website resmi Bursa Efek Indonesia (BEI) yaitu www.idx.co.id.

\section{HASIL DAN PEMBAHASAN}

\subsection{Analisis Statistik Deskriptif}

Hasil statistik deskriptif data keputusan investasi, keputusan pendanaan, profitabilitas dan nilai perusahaan dalam penelitian ini dapat dilihat pada tabel 2 . Keputusan investasi (X1) yang diproksikan dengan Price Earning Ratio (PER) memiliki nilai mean sebesar 17,39x dengan nilai standar deviasinya sebesar 6,72x. Keputusan pendanaan (X2) yang diproksikan dengan Debt to Equity Ratio (DER) memiliki mean sebesar 2,51x dengan nilai standar deviasinya sebesar 2,68x. Profitabilitas $(Z)$ yang diproksikan dengan Return on Equity (ROE) memiliki nilai minimum sebesar 0,88\% dan nilai maksimum sebesar $44,57 \%$. Sedangkan nilai mean sebesar $14,87 \%$ dengan nilai standar deviasinya sebesar $6,51 \%$. Nilai perusahaan (Y) yang diproksikan dengan Tobins' $Q$ memiliki nilai minimium sebesar $0,43 x$ dan nilai maksimum sebesar10,18x. Sedangkan nilai mean sebesar $1,84 x$ dengan nilai standar deviasinya sebesar 1,55x.

Tabel 2. Analisis Statistik Deskriptif

\begin{tabular}{|l|c|c|c|c|}
\hline \multicolumn{1}{|c|}{ Variabel } & N & Min. & Maks. & SD \\
\hline PER $(X)$ & 101 & 5,75 & 32,96 & 6,72 \\
\hline DER $(X)$ & 101 & 0,19 & 11,40 & 2,68 \\
\hline ROE $(\%)$ & 101 & 0,88 & 44,57 & 6,51 \\
\hline Tobin's Q $(X)$ & 101 & 0,43 & 10,18 & 1,55 \\
\hline
\end{tabular}

Sumber : Data sekunder yang diolah

\subsection{Hasil Koefisien Determinasi}

Hasil pengujian koefisien determinasi data keputusan investasi, keputusan pendanaan dan profitabilitas terhadap nilai perusahaan dalam penelitian ini dapat dilihat pada tabel 3. Nilai koefisien determinasi atau $R$ Square adalah sebesar 0,604 atau $60,4 \%$ dan adjusted $R$ Square sebesar 0,592 atau 59,2\% yang berarti bahwa variabel keputusan investasi (X1), keputusan pendanaan (X2) dan profitabilitas (Z) secara simultan berpengaruh terhadap nilai perusahaan $(Y)$ sebesar 59,2\%. Sedangkan sisanya $(100 \%-59,2 \%=40,8 \%)$ dipengaruhi oleh variabel lain di luar persamaan regresi ini atau variable yang tidak diteliti. 
Tabel 3. Uji Koefisien Determinasi dengan Model Summary Terhadap Nilai Perusahaan

\begin{tabular}{|c|c|c|}
\hline \multicolumn{3}{|c|}{ Model Summary } \\
\hline Model & Adjusted R Square & Std. Error of the Estimate \\
\hline 1 & 0,592 & 0,99519 \\
\hline \multicolumn{3}{|c|}{$\begin{array}{l}\text { a. Predictors: (Constant), Profitabilitas (Z), Keputusan Pendanaan (X2), } \\
\text { Keputusan Investasi (X1) }\end{array}$} \\
\hline \multicolumn{3}{|c|}{ b. Dependent Variable : Nilai Perusahaan $(\mathrm{Y})$} \\
\hline
\end{tabular}

\subsection{Hasil Uji t Terhadap Profitabilitas}

Hasil pengujian simultan $t$ data keputusan investasi dan keputusan pendanaan terhadap profitabilitas dalam penelitian ini dapat dilihat pada tabel 4 . Pengujian pengaruh keputusan investasi terhadap profitabilitas, menunjukkan nilai $\mathrm{t}$ keputusan investasi sebesar 1,721 pada signifikansi 0,088 $\geq 0,05$ yang artinya berdasarkan dasar pengambilan keputusan uji $\mathrm{t}$ apabila nilai signifikansi lebih besar dari 0,05 maka hipotesis ditolak. Dengan kata lain keputusan investasi (X1) tidak berpengaruh terhadap profitabilitas. Sedangkan pengujian pengaruh keputusan pendanaan terhadap profitabilitas, menunjukkan nilai $\mathrm{t}$ keputusan pendanaan sebesar 0,991 pada signifikansi $0,324 \geq 0,05$ yang artinya berdasarkan dasar pengambilan keputusan uji t apabila nilai signifikansi lebih besar dari 0,05 maka hipotesis ditolak. Dengan kata lain keputusan pendanaan (X2) tidak berpengaruh terhadap profitabilitas.

Tabel 4. Uji t dengan Coefficients Terhadap Profitabilitas

\begin{tabular}{|c|c|c|c|c|}
\hline \multicolumn{5}{|c|}{ Coefficients $^{a}$} \\
\hline \multirow{2}{*}{\multicolumn{2}{|c|}{ Model }} & $\begin{array}{l}\text { Unstandardized } \\
\text { Coefficients }\end{array}$ & $\mathrm{t}$ & Sig. \\
\hline & & $\mathrm{B}$ & & \\
\hline \multirow{3}{*}{1} & (Constant) & 12,430 & 5,581 & 0,000 \\
\hline & Keputusan Investasi (X1) & 0,177 & 1,721 & 0,088 \\
\hline & Keputusan Pendanaan (X2) & $-.0,256$ & $-0,991$ & 0,324 \\
\hline & dent Variable: Profitabilitas ( $Z$ & & & \\
\hline
\end{tabular}

\subsection{Hasil Uji t Terhadap Nilai Perusahaan}

Hasil pengujian simultan $t$ data keputusan investasi, keputusan pendanaan dan profitabilitas terhadap nilai perusahaan dalam penelitian ini dapat dilihat pada tabel 5 berikut. Pengujian pengaruh keputusan investasi terhadap nilai perusahaan, menunjukkan nilai t keputusan investasi (X1) sebesar 5,778 pada signifikansi 0,000 $\leq 0,05$ yang artinya berdasarkan dasar pengambilan keputusan uji $\mathrm{t}$ apabila nilai sig. $\leq 0,05$ maka hipotesis diterima atau keputusan investasi (X1) berpengaruh terhadap nilai perusahaan (Y). Pada pengujian pengaruh keputusan pendanaan terhadap nilai perusahaan, menunjukkan nilai $t$ untuk keputusan pendanaan (X2) adalah sebesar $-1,583$ pada signifikansi 0,117 $\geq 0,05$ yang artinya berdasarkan dasar pengambilan keputusan uji $t$ apabila nilai signifikansi $\geq 0,05$ maka hipotesis ditolak atau keputusan pendanaan (X2) tidak berpengaruh terhadap nilai perusahaan $(\mathrm{Y})$. Sedangkan pengujian pengaruh profitabilitas terhadap nilai perusahaan, menunjukkan nilai $t$ untuk profitabilitas $(Z)$ adalah sebesar 7,928 pada signifikansi $0,000 \leq$ 0,05 yang artinya berdasarkan dasar pengambilan keputusan uji t apabila nilai signifikansi $\leq 0,05$ maka hipotesis diterima atau profitabilitas $(Z)$ berpengaruh terhadap nilai perusahaan $(\mathrm{Y})$. 
Tabel 5. Uji t dengan Coefficients Terhadap Nilai Perusahaan

\begin{tabular}{|c|c|c|c|c|}
\hline \multicolumn{5}{|c|}{ Coefficients $^{a}$} \\
\hline \multicolumn{2}{|r|}{ Model } & Unstandardized & $\mathrm{t}$ & Sig. \\
\hline \multirow{4}{*}{1} & (Constant) & $-1,495$ & $-3,746$ & 0,000 \\
\hline & Keputusan Investasi (X1) & 0,094 & 5,778 & 0,000 \\
\hline & Keputusan Pendanaan (X2) & $-0,064$ & 01,583 & 0,117 \\
\hline & Profitabilitas (Z) & 0,125 & 7,928 & 0,000 \\
\hline
\end{tabular}

Sumber: Data sekunder yang diolah

\subsection{Analisis Jalur Path (Path Analysis)}

Hasil pengujian jalur path (path analysis) dalam penelitian ini adalah sebagai berikut:

1. Pengaruh keputusan investasi terhadap nilai perusahaan dengan profitabilitas sebagai varibel mediasi $(\mathrm{p} 2 \times \mathrm{p} 3)=0,177 \times 0,125=0,022125$

Dari hasil tersebut pengaruh mediasinya signifikan atau tidak dapat dilihat melalui pengujian berikut:

$$
\begin{aligned}
& \text { Sp2p3 }=\sqrt{ } p 3^{2} S p 2^{2}+p 2^{2} S p 3^{2}+S p 2^{2} S p 3^{2} \\
& \text { Sp2p3 }=\sqrt{ }(0,125)^{2}(0,103)^{2}+(0,177)^{2}(0,016)^{2}+(0,103)^{2}(0,016)^{2} \\
& \text { Sp2p3 }=\sqrt{ } 0,0001765018=0,013285 \\
& \mathrm{t}=\frac{\mathrm{Sp} 3}{\mathrm{Sp} 2 \mathrm{p} 3}=\frac{0,022125}{0,013285}=1,66541
\end{aligned}
$$

2. Pengaruh keputusan pendanaan terhadap nilai perusahaan dengan profitabilitas sebagai varibel mediasi $(\mathrm{p} 2 \times \mathrm{p} 3)=-0,256 \times 0,125=-0,032$

Dari hasil tersebut pengaruh mediasinya signifikan atau tidak dapat dilihat melalui pengujian berikut :

$$
\begin{aligned}
& \text { Sp2p3 }=\sqrt{ } p 3^{2} S p 2^{2}+p 2^{2} S p 3^{2}+S p 2^{2} S p 3^{2} \\
& \text { Sp2p3 }=\sqrt{(0,125)^{2}(0,258)^{2}+(-0,256)^{2}(0,016)^{2}+(0,258)^{2}(0,016)^{2}} \\
& \text { Sp2p3 }=\sqrt{0,0010738801}=0,0327701 \\
& \mathrm{t}=\frac{\text { Sp3 }}{\text { Sp2 } 3}=\frac{-0,032}{0,0327701}=-0,97649
\end{aligned}
$$

Tabel 6. Hasil Analisis Jalur (Path Analysis)

\begin{tabular}{|l|c|c|c|c|}
\hline \multicolumn{1}{|c|}{ Model } & Kofisien & $\begin{array}{c}\text { Uji Sobel } \\
\text { Test } \\
\text { (t hitung) }\end{array}$ & t tabel & Ket. \\
\hline $\begin{array}{l}\text { Pengaruh Keputusan Investasi terhadap Nilai } \\
\text { Perusahaan dengan profitabilitas sebagai } \\
\text { variabel Mediasi }\end{array}$ & 0,02213 & 1,66541 & 1,98373 & $\begin{array}{c}\text { Tidak } \\
\text { Signifikan }\end{array}$ \\
\hline $\begin{array}{l}\text { Pengaruh Keputusan Pendanaan terhadap } \\
\text { Nilai Perusahaan dengan profitabilitas sebagai } \\
\text { variabel Mediasi }\end{array}$ & $-0,032$ & $-0,97649$ & 1,98373 & $\begin{array}{c}\text { Tidak } \\
\text { Signifikan }\end{array}$ \\
\hline
\end{tabular}

Sumber : Data sekunder yang diolah

Hasil pengujian pengaruh keputusan investasi terhadap nilai perusahaan dengan profitabilitas sebagai variabel mediasi, menunjukkan hasil koefisien sebesar 0,02213 dengan hasil uji sobel test sebesar 1,66541 lebih kecil dari t tabel pada signifikansi 0,05 yaitu sebesar 1,98373 yang artinya pengaruh keputusan investasi terhadap nilai perusahaan yang dimediasi oleh profitabilitas tidak berpengaruh signifikan atau profitabilitas tidak mampu memediasi pengaruh keputusan investasi terhadap nilai perusahaan. Sedangkan hasil 
pengujian pengaruh keputusan pendanaan terhadap nilai perusahaan dengan profitabilitas sebagai variabel mediasi, menunjukkan hasil koefisien sebesar -0,032 dengan hasil uji sobel test sebesar 0,97649 lebih kecil dari t tabel pada signifikansi 0,05 yaitu sebesar 1,98373 yang artinya pengaruh keputusan pendanaan terhadap nilai perusahaan yang dimediasi oleh profitabilitas tidak berpengaruh signifikan atau profitabilitas tidak mampu memediasi pengaruh keputusan pendanaan terhadap nilai perusahaan.

\subsection{Pembahasan Hasil Penelitian}

\subsubsection{Pengaruh Keputusan Investasi Terhadap Profitabilitas}

Hasil pengujian hipotesis pertama (H1) ditolak dan menunjukkan bahwa keputusan investasi berpengaruh positif tidak signifikan terhadap profitabilitas. Semakin tinggi keputusan investasi maka semakin tinggi kesempatan perusahaan dalam memperoleh return atau tingkat pengembalian yang besar. Tingkat pengembalian yang besar diartikan sebagai sinyal positif atau keberhasilan perusahaan dalam menginvestasikan dana yang dimiliki pada sesuatu yang tepat, sehingga perusahaan akan bertumbuh meningkatnya laba dapat menarik investor untuk melakukan investasi atau penanaman modal ke perusahaan. Hasil penelitian ini sejalan dengan penelitian yang dilakukan oleh Safitri dan Wahyuati (2015), Purnama (2018) dan Ginting (2019) mengatakan bahwa keputusan investasi berpengaruh positif terhadap nilai perusahaan.

\subsubsection{Pengaruh Keputusan Pendanaan Terhadap Profitabilitas}

Hasil pengujian hipotesis kedua (H2) ditolak dan menunjukkan bahwa keputusan pendanaan berpengaruh negatif dan tidak signifikan terhadap profitabilitas.Trade-off theory menyatakan penggunaan hutang akan meningkatkan nilai perusahaan tetapi hanya pada sampai titik tertentu. Apabila memaksa menggunakan hutang maka perusahaan akan mengalami penurunan profitabilitas. Hasil menunjukkan bahwa peningkatan hutang pada perusahaan LQ45 maka akan berdampak pada penurunan profitabilitas. Hasil penelitian ini sejalan dengan penelitian yang dilakukan oleh Purnama (2018) yang mengatakan bahwa keputusan pendanaan berpengaruh negatif dan tidak signifikan terhadap profitabilitas.

\subsubsection{Pengaruh Keputusan Investasi Terhadap Nilai Perusahaan}

Hasil pengujian hipotesis ketiga (H3) diterima dan menunjukkan bahwa keputusan investasi berpengaruh positif dan signifikan terhadap nilai perusahaan. Hal ini menunjukkan bahwa semakin tinggi keputusan investasi maka semakin tinggi pula nilai perusahaan dan manajer berhasil menciptakan keputusan investasi yang tepat (Suroto, 2015). Aset yang diinvestasikan menghasilkan kinerja yang optimal sehingga akan memberikan sinyal positif kepada investor yang nantinya akan meningkatkan harga saham dan nilai perusahaan. Hasil penelitian ini sejalan dengan penelitian yang dilakukan oleh Sartini dan Purbawangsa (2014), Suroto (2015) serta Maimun dan Hilal (2014).

\subsubsection{Pengaruh Keputusan Pendanaan terhadap Nilai Perusahaan}

Hasil pengujian hipotesis keempat (H4) menunjukkan bahwa hipotesis ditolak karena keputusan investasi berpengaruh negatif dan tidak signifikan terhadap nilai perusahaan. Berdasarkan trade off theory, kenaikan hutang akan bermanfaat jika dapat meningkatkan nilai perusahaan, artinya bahwa penambahan hutang belum mencapai titik optimal dimana suatu batas optimal dari jumlah hutang yang dapat menyebabkan nilai perusahaan tersebut maksimal. Jika penggunaan hutang melewati batas, penggunaan akan menyebabkan turunnya nilai perusahaan. Manfaat hutang (penghematan pajak) lebih kecil dari biaya yang timbul akibat berhutang berupa biaya keagenan dan biaya kebangkrutan. Hasil penelitian ini sejalan dengan penelitian yang dilakukan oleh Suroto (2015), Maulana et. al. (2016), Kumalasari dan Riduwan (2018), serta Cahyono dan Sulistyawati (2016). 


\subsubsection{Pengaruh Profitabilitas Terhadap Nilai Perusahaan}

Berdasarkan tabel uji $\mathrm{t}$ dapat dilihat bahwa hipotesis kelima (H5) yang mengatakan bahwa profitabilitas berpengaruh positif terhadap nilai perusahaan diterima. Signaling theory merupakan tindakan dimana manajemen perusahaan memberikan petunjuk bagi investor tentang bagaimana manajemen memandang prospek perusahaan. Semakin tinggi profitabilitas suatu perusahaan dapat menunjukkan kemampuan perusahaan mengelola aset dan modal yang dimiliki untuk menghasilkan laba, sehingga akan berdampak positif terhadap nilai perusahaan. Hasil penelitian ini sejalan dengan penelitian yang dilakukan oleh Indriyani (2017), Dewi dan Wirajaya (2013), serta Prasetyorini (2013) mengatakan bahwa profitabilitas berpengaruh positif dan signifikan terhadap nilai perusahaan.

\subsubsection{Pengaruh Keputusan Investasi Terhadap Nilai Perusahaan dengan Profitabilitas sebagai Variabel Mediasi}

Setelah dilakukannya pengujian maka didapat hasil pengaruh keputusan investasi terhadap nilai perusahaan yang dimediasi oleh profitabilitas tidak berpengaruh signifikan. Profitabilitas tidak mampu memediasi pengaruh keputusan investasi terhadap nilai perusahaan, dengan demikian hipotesis keenam (H6) ditolak. Investasi adalah penanaman sumber daya untuk mendapatkan hasil dimasa yang akan datang. Investasi memiliki resiko yang cukup tinggi karena apabila tingkat pengembalian tidak sesuai dengan yang diharapkan secara langsung dapat memengaruhi persepsi investor terhadap perusahaan. Selain itu, investasi dimasa datang tidak dapat mempengaruhi kepercayaan investor untuk menginvestasikan sejumlah dananya kepada perusahaan. Pengambilan keputusan investasi yang tidak tepat akan berdampak pada penurunan kinerja perusahaan sehingga para investor akan merespon negatif hal tersebut dan menyebabkan turunnya harga saham dan penurunan profitabilitas. Turunnya profitabillitas ini tentunya akan berdampak pula pada penurunan nilai perusahaan. Hasil penelitian ini sejalan dengan penelitian yang dilakukan oleh Anisa (2019) yang menyatakan bahwa profitabilitas tidak mampu memediasi pengaruh keputusan investasi terhadap nilai perusahaan.

\subsubsection{Pengaruh Keputusan Pendanaan terhadap Nilai Perusahaan dengan Profitabilitas sebagai Variabel Mediasi}

Hasil pengujian menunjukkan bahwa pengaruh keputusan pendanaan terhadap nilai perusahaan yang dimediasi oleh profitabilitas tidak berpengaruh signifikan. Sehingga, hipotesis ketujuh (H7) yang mengatakan bahwa profitabilitas mampu memediasi keputusan pendanaan terhadap nilai perusahaan dinyatakan ditolak. Perusahaan yang memiliki hutang yang besar cenderung memiliki profitabilitas rendah karena sebagian dari perolehan tersebut akan digunakan untuk membayar bunga dari pinjaman yang cukup besar. Ini dikarenakan manajer terlalu mengandalkan pembiayaan melalui hutang sehingga beban dan resiko yang ditanggung oleh perusahaan semakin besar karena adanya biaya bunga yang harus dibayar. Para investor akan menangkap ini sebagai sinyal negatif, karena tujuan utamanya adalah melakukan investasi dengan harapan mendapatkan profitabilitas yang tinggi. Namun apabila yang terjadi malah sebaliknya maka investor akan lebih memilih menginvestasikan dananya ke perusahaan lain sehingga ini juga berdampak pada penurunan nilai perusahaan. Hasil penelitian ini juga sejalan dengan penelitian yang dilakukan oleh Kurniawan (2015) yang mengatakan bahwa profitabilitas tidak mampu memediasi pengaruh struktu modal terhadap nilai perusahaan. 


\section{KESIMPULAN}

Penelitian ini bertujuan untuk menguji pengaruh keputusan investasi dan keputusan pendanaan terhadap nilai perusahaan dengan profitabilitas sebagai variabel mediasi pada perusahaan yang termasuk ke dalam indeks LQ45 periode 2015-2019. Hasil pengujian menunjukkan keputusan investasi berpengaruh positif dan tidak signifikan terhadap profitabilitas. Keputusan pendanaan berpengaruh negatif dan tidak signifikan terhadap profitabilitas. Keputusan investasi berpengaruh positif dan signifikan terhadap nilai perusahaan, sedangkan keputusan pendanaan berpengaruh negatif dan tidak signifikan terhadap nilai perusahaan. Pengambilan keputusan investasi yang tepat membuat aset yang diinvestasikan akan menghasilkan kinerja yang optimal sehingga akan memberikan sinyal positif kepada investor yang nantinya akan meningkatkan harga saham dan nilai perusahaan. Keputusan pendanaan berpengaruh negatif dan tidak signifikan terhadap nilai perusahaan. Berdasarkan trade off theory, kenaikan hutang akan bermanfaat jika dapat meningkatkan nilai perusahaan. Jika penggunaan hutang melewati batas, penggunaan akan menyebabkan turunnya nilai perusahaan. Profitabilitas berpengaruh positif dan signifikan terhadap nilai perusahaan, dimana semakin tinggi profitabilitas suatu perusahaan dapat menunjukkan kemampuan perusahaan dalam menghasilkan laba, sehingga akan berdampak positif terhadap harga saham dan peningkatan nilaiperusahaan. Sedangkan hasil pengujian mediasi menunjukkan bahwa profitabilitas tidak mampu memediasi pengaruh keputusan investasi dan keputusan pendanaan terhadap nilai perusahaan.

\section{DAFTAR PUSTAKA}

Achmad, S. L., \& Amanah, L. (2014). Pengaruh Keputusan Investasi, Keputusan Pendanaan, Kebijakan Deviden dan Kinerja Keuangan terhadap Nilai Perusahaan. Jurnal Ilmu \& Riset Akuntansi, 3(9).

Alipudin, A., \& Hidayat, N. (2014). Keputusan Investasi,Pendanaan, Kebijakan Deviden dan Price to Book Value Perusahaan Pertambangan di Bursa Efek Indonesia. Jurnal Riset Akuntansi dan Perpajakan (JRAP), 1(1), 48-59.

Anisa, H. (2019). Pengaruh Struktur Modal, Ukuran Perusahaan dan Keputusan Investasi terhadap Nilai Perusahaan dengan Profitabilitas sebagai Variabel Intervening. Skripsi.

Bararuallo, F. (2011). Nilai Perusahaan Konsep, Teori, dan Aplikasi. Jakarta: Universitas Atma Jaya.

Cahyono, H. S., Sulistyawati, A. I. (2016). Keputusan Investasi, Keputusan Pendanaan Dan Kebijakan Dividen Sebagai Determinan Nilai Perusahaan. Akuisisi, 12(2), 39-53.

Dewi, A. S., \& Wirajaya, A. (2013). Pengaruh Struktur Modal, Profitabilitas dan Ukuran Perusahaan pada Nilai Perusahaan. E-Jurnal Akuntansi Universitas Udayana, 4(2), 358-372.

Ginting, G. (2019). Pengaruh Ukuran Perusahaan, Pertumbuhan Perusahaan, Keputusan Investasi, dan Struktur Modal terhadap Profitabilitas Perusahaan Property, Konstruksii dan Real Estate yang terdaftar di Bursa Efek Indonesia Periode 20072017. TEDC, 13(2), 119-126.

Gustian, D. (2017). Pengaruh Pertumbuhan Perusahaan, Keputusan Investasi, dan Keputusan Pendanaan terhadap Nilai Perusahaan. Jurnal Akuntansi, 5(2), 1-23.

Hardiyanti, N. (2012). Analisis Pengaruh Insider Ownership, Leverage, Profitabilitas, Firm Size dan Dividen Payout Ratio Terhadap Nilai Perusahaan (Studi Pada Perusahaan Manufaktur Yang Terdaftar di BEI Tahun 2007-2010. Skripsi. 
Husnan, S. (1996). Manajemen Keuangan Teori dan Penerapan (Keputusan Jangka Panjang). Yogyakarta: BPFE-YOGYAKARTA.

Husnan, S. (2000). Manajemen Keuangan Teori dan Penerapan (Keputusan Jangka Panjang) Buku 1. Yogyakarta: BPFE

Indriyani, E. (2017). Pengaruh Ukuran Perusahaan dan Profitabilitas terhadap Nilai Perusahaan. Akuntabilitas : Jurnal Ilmu Akuntansi, 10(2), 333-348.

Kelana, S. K., \& Amanah, L. (2020). Pengaruh Pertumbuhan Perusahaan dan Keputusan Investasi terhadap Nilai Perusahaan dengan Profitabilitas sebagai Variabel Intervening. Jurnal Ilmu dan Riset Akuntansi, 9(1), 1-22 .

Kumalasari, D., \& Riduwan, A. (2018). Pengaruh Keputusan Investasi, Keputusan Pendanaan, dan Kebijakan Deviden Terhadap Nilai Perusahaan. Jurnal Ilmu dan riset Akuntansi, 7(1), 1-20.

Kurniawan, M. S. (2015). Intervensi Profitabilitas dalam pengaruh Investment Opportunity Set (IOS) dan Struktur Modal terhadap Nilai Perusahaan Publik Sektor Industri Manufaktur di Indonesia Tahun 2011-2013. Skripsi.

Lindenberg, E. B., Stephen A. R. (1981). Tobin's q Ratio and Industrial Organization. The Journal of Business, 54(1), 1-32.

Maimunah, S., \& Hilal, S. (2014). Pengaruh Keputusan Investasi, Keputusan Pendanaan, Kebijakan Deviden dan Tingkat Suku Bunga terhadap Nilai Perusahaan. Jurnal Ilmiah Manajemen dan Akuntansi Fakultas Ekonomi (JIMAFE), 6(2), 42-49.

Mardiyati, U., Abrar, M., \& Ahmad, G. N. (2015). Pengaruh Keputusan Investasi, Keputusan Pendanaan, Ukuran Perusahaan Dan Profitabilitas Terhadap Nilai Perusahaan Pada Sektor Manufaktur Barang Konsumsi Yang Terdaftar Di Bursa Efek Indonesia Periode 2010-2013. Jurnal Riset Manajemen Sains Indonesia, 6(1), 417439.

Maulana, M. R., Hermanto, \& Putra, I. N. (2016). Pengaruh Keputusan Investasi, Keputusan Pendanaan dan Kebijakan Deviden terhadap Nilai Perusahaan pada Perusahaan LQ45 di Bursa Efek Indonesia tahun 2011-2015. Jurnal Distribusi, Jurnal Ilmu Manajemen dan Bisnis, 4(2), 29-50.

Munawir, S. (2014). Analisis Laporan Keuangan. Yogyakarta : Liberty.

Muvidha, N. I., \& Suryono, B. (2017). Pengasuh Struktur Kepemilikan, Keputusan Pendanaan, Profitabilitas dan Ukuran Perusahaan terhadap Nilai Perushaan. Jurnal Ilmu dan Riset Akuntansi, 6(5), 1813-1835.

Pamungkas, H. S., \& Puspaningsih, A. (2013). Pengaruh Keputusan Investasi, Keputusan Pendanaan, Kebijakan Dividen dan Ukuran Perusahaan terhadap Nilai Perusahaan. Jurnal Akuntnasi dan Auditing Indoesia, 17(2), 156-165.

Prasetyorini, B. F. (2013). Pengaruh Ukuran Perusahaan, Laverage, Price Earning Ratio dan Profitabilitas terhadap Nilai Perusahaan. Jurnal Ilmu Manajemen, 1(1), 183-196.

Purnama, H. (2018). Pengaruh Struktur Modal, Kebijakan Deviden, dan Keputusan Investasi terhadap Profitabilitas. Jurnal Akuntansi \& Manajemen Aknenika, 15(2), 122-134.

Rini, D. P., \& Winarmo. (2016). Pengaruh Profitabilitas, Keputusan Pendanaan, Keputusan Investasi, dan Keputusan Deviden terhadap Nilai Perusahaan pada Perusahaan yang Termasuk dalam Indeks LQ45. Jurnal Manajemen Bisnis Indonesia (JMBI), 5(1), 73-81.

Safitri, N., \& Wahyuati, A. (2015). Pengaruh Struktur Modal dan Keputusan Investasi Terhadap Profitabilitas dan Nilai Perusahaan. Jurnal Ilmu dan Riset Manajemen, $4(2)$. 
Salim, U., \& Moeljadi. (2001). Dasar-dasar Manajemen Keuangan. Malang: Lembaga Manajemen Fakultas Ekonomi Unibraw.

Sari, N. M., \& Budiasih, I. G. (2014). Pengaruh Debt to Equity Ratio, Firm Size, Inventory Turnover dan Assets Turnover pada Profitabilitas. E-Jurnal Akuntansi Universitas Udayana, 6(2), 261-273.

Sartini, L. P., \& Purbawangsa, I. B. (2014). Pengaruh Keputusan Investasi, Kebijakan Deviden, serta Keputusan Pendanaan terhadap Nilai Perusahaan Manufaktur di Bursa Efek Indonesia. Jurnal Manajemen, Strategi Bisnis dan Kewirausahaan, 8(2), 8190.

Sartono, A. (2001). Manajemen Keuangan Teori dan Aplikasi Edisi 4. Yogyakarta: BPFEYogyakarta.

Septiani, D. (2019). Pengaruh Ukuran Perusahaan, Umur Perusahan, Laverage dan Keputusan Investasi terhadap Nilai Perusahaan dengan Profitabilitas sebagai Variabel Intervening. Skripsi

Setiawan, R., \& Sudiro, K. (2019). Pengaruh Investasi terhadap Profitabilitas Anggota Holding PT Pupuk Indonesia (PERSERO). Jurnal STIE SEMARANG, 11(2).

Suroto, S. (2015). Pengaruh Keputusan Investasi, Keputusan Pendanaan dan Kebijakan Dividen terhadap Nilai Perusahaan. Jurnal Ilmiah UNTAG Semarang, 4(3), 100-117. 